students in the educational process of higher school: organizational and methodological aspects]: navchal'no-metodychnyy posibnyk. Bila Tserkva. [in Ukrainian].

Dubasenyuk, O.A., Yaksa, N.V. (2010). Problema polikul'turnoyi pidhotovky studentiv u zarubizhniy pedahohichniy nautsi i praktytsi [The problem of multicultural training of students in foreign pedagogical science and practice]. Profesijna osvita: pedagogika i psihologiya - Vocational education: pedagogy and psychology. Pol's'ko-ukraïns'kij, ukraïno-pol's'kij shchorichnik. Levovic'kij, T., Vil'sh, I., Zyazyun, I., Nichkalo, N. (Ed.). Chenstohova-Kiïv. [in Ukrainian].

Zhernov, V.I. (1999). Teoretiko-metodologicheskiye osnovy formirovaniya professional'no-pedagogicheskoy napravlennosti lichnosti studenta pedagogicheskogo vuza [Theoretical and methodological foundations of the formation of the professional and pedagogical orientation of the personality of a student of a pedagogical university]. Magnitogorsk: Magnitogorskij gos. ped. in-tut. [in Russian].

Zvereva, M.V. (1987). O ponyatii «didakticheskiye usloviya» [About the concept of "didactic conditions»] Novye issledovaniya $v$ pedagogicheskih naukah. Samojlova, V.S. (Ed.). M.: Pedagogika - Pedagogy. [in Russian].

Zelens'ka, O.M. (2012). Formuvannya polikul'turnoyi kompetentnosti kursantiv vyshchykh viys'kovykh navchal'nykh zakladiv u protsesi vyvchennya humanitarnykh dystsyplin [Formation of multicultural competence of cadets of higher military educational institutions in the process of studying humanities]. Candidate's thesis. Harkiv. [in Ukrainian].

Lomov, B.F. (2002) Obshchenie: ponyatie, formy. Psihologicheskij zhurnal Psychological journal, 6, $26-27$. [in Russian].

Filosofiya intehratsiyi [Philosophy of integration]: monografiya. Bondarenko, V.D., Vashchuk, F.G. (Ed.). Uzhgorod: ZakDU, 2011. [in Ukrainian].

УДК 378.046.4: 373.58/.5.091.2.011.3-051:51]:004

DOI: https://doi.org/10.35387/od.2(18).2020.97-105

Мар'єнко Майя Володимирівна - кандидат педагогічних наук, старший науковий співробітник відділу хмаро орієнтованих систем інформатизації освіти Інституту інфоормаційних технологій $і$ засобів навчання НАПН України

ORCID iD: https://orcid.org/0000-0002-8087-962X

E-mail:popelmaya@gmail.com

\title{
КОМПЕТЕНТНОСТІ ВІДКРИТОЇ НАУКИ ВЧИТЕЛІВ ПРИРОДНИЧО-МАТЕМАТИЧНИХ ДИСЦИПЛІН
}

Анотація. В оглядовій статті розглянуто компетентності відкритої науки в широкому значенні та як складник профресійної компетентності вчителя природничо-математичних предметів для 
роботи в науковому ліцеї. Зокрема, розкрито зміст поняття «відкрита наука» задля подальшого визначення складників компетентностей відкритої науки. Визначено основні складники компетентностей відкритої науки, виокремлено чотири категорії: навички та досвід, необхідні для публікації у відкритому доступі; навички та досвід щодо даних досліджень, виробництва даних, управління, аналізу / використання / повторного використання, поширення та зміни парадигми з «захищені дані за замовчуванням» на "відкриті дані за замовчуванням», дотримуючись законодавчих та інших обмежень; навички та досвід роботи у власній науковій та дисциплінарній спільноті та поза нею; навички та досвід, що випливають із загальної та широкої концепиії науки, коли дослідники взаємодіють із широкою громадськістю, щоб посилити вплив науки та досліджень. Серед категорій компетентностей відкритої науки було встановлено: компетентності публікації у відкритому доступі (бібліотечні та дослідницькі інфрормаційні навички, навички грамотності у відкритих публікаціях); компетентності управлінням даними та відкритими даними (технічні навички, навички у галузі інфоормаційних технологій); компетентності проведення профресійних досліджень (навички управління дослідженнями, юридичні навички, дослідження иілісності та навички етики); компетентності суспільної науки. Запропоновано шляхи оволодіння компетентностями відкритої науки: конкуренції та співпраці; використання хмарних сервісів відкритої науки; використання та повторне використання відкритих даних; впровадження принципів відкритої науки не лише серед науковців, але й в галузі педагогіки.

Ключові слова: відкрита наука; компетентності відкритої науки; вчителі природничо-математичних предметів; наукові ліцеї.

Marienko Maiia - Candidate of Pedagogical Sciences, Senior Researcher, Department of Cloud-Oriented Systems of Education Informatization, Institute of Information Technologies and Learning Tools of NAES of Ukraine

ORCID iD: https://orcid.org/0000-0002-8087-962X

E-mail:popelmaya@gmail.com

\section{THE OPEN SCIENCE COMPETENCIES OF TEACHERS OF NATURAL AND MATHEMATICAL SUBJECTS}

Abstract. The review article considers the competencies of open science in a broad sense and as a component of the professional competencies of a teacher of natural sciences and mathematics to work in a scientific lyceum. In particular, the meaning of the concept of "open science» is revealed, in order to further define the components of the competences of open science. The main 
components of open science competencies have been identified and divided into four categories: skills and experience required for open access publishing; skills and experience in research data, data production, management, analysis / use / reuse, dissemination and paradigm shift from "protected default data" to "open default data», subject to legal and other restrictions; skills and experience in their own scientific and disciplinary community and beyond; skills and experience derived from the general and broad concept of science, where researchers interact with the general public to enhance the impact of science and research. Among the categories of open science competencies the main components relevant for teachers were established: open access publishing competencies (library and research information skills, literacy skills in open publications); competences in data management and open data (technical skills, skills in the field of information technology); competences to conduct professional research (research management skills, legal skills, integrity research and ethics skills); competence of social science. The ways to master the competencies of open science are proposed: competition and cooperation; the use of open science cloud services; the use and reuse of open data; introduction of the principles of open science not only among scientists, but also among educators.

Key words: open science; competences of open science; teachers of natural sciences and mathematics; scientific lyceums.

Постановка проблеми, іï актуальність. Набуття компетентностей відкритої науки вчителями природничо-математичних дисциплін у наукових ліцеях має відігравати важливу роль у розвиткові дослідницького потенціалу учнів. Йдеться про значний вплив на цілісність досліджень, що дозволить вчителям наукових ліцеїв та їх учням уникнути плагіату, маніпулювання даними та їх фральсифікації тощо. Розвиток компетентностей відкритої науки має стати пріоритетним напрямом діяльності наукових ліцеїв, що дозволить розвивати в учнів здатність здійснювати правдиву наукову діяльність, а у подальшому сприятиме зміцненню наукового потенціалу країни.

Відкрита наука уособлює підхід до організації досліджень, які є спільними, прозорими та доступними, та охоплює широкий спектр діяльності, включаючи публікацію у відкритому доступі, відкриті дані досліджень, відкриті препринти, відкриту експертну оцінку результатів та відкриту освіту. Також дотичним в даному контексті $є$ таке поняття як наука для громадян, де кожен громадянин держави має безпосереднє відношення до участі у дослідженнях.

Рушійною силою відкритої науки є посилення прозорості процесу досліджень та обґрунтованості результатів, а також суспільне право власності на наукові розробки, особливо на ті, що фінансуються державою. 
Відкрита наука пов'язана з цілісністю досліджень і вимагає правової та етичної обізнаності з боку дослідників. Компетентності відкритої науки охоплюють широкий спектр складників: від управління даними до юридичних аспектів організації, а також містять технічні компетентності, такі як управління даними, захист даних, наукове спілкування та розповсюдження (включаючи створення метаданих).

Важливого значення набуває те, щоб не лише дослідники, але й вчителі природничо-математичних предметів, що працюють (або працюватимуть) у науковому ліцеї, мали можливість професійно розвиватися, удосконалювати відповідні навички, необхідні для того, щоб повною мірою діяти відповідно до принципів відкритої науки. Професійний розвиток супроводжує всі етапи дослідження, що стає каталізатором для зміни культури проведення досліджень. Ці зміни в мисленні та культурі, підкріплені модернізацією сектора вищої освіти, у свою чергу, мають бути підтримані університетами / науково-дослідними установами, фінансуючими установами та європейською, регіональною та національною політикою (Providing researchers with the skills and competencies they need to practise Open Science, 2017).

Аналіз останніх досліджень і публікацій. T. Ignat та P. Ayris (Ignat, \& Ayris, 2020) в своєму дослідженні розглянули шляхи набуття та розвитку компетентностей відкритої науки: розвиток навичок роботи в команді, налагоджене керівництво, використання інструментів відкритої науки та залучення ресурсів та раціональний розподіл ресурсів (коштів, часу та хмарних сервісів).

Дослідники B. Schmidt, A. Orth, G. Franck, I. Kuchma, P. Knoth та J. Carvalho (Schmidt, Orth, Franck, Kuchma, Knoth, \& Carvalho, 2016) B проєкті FOSTER (в рамках якого було розроблено портал FOSTER) надають певні рекомендації з приводу набуття компетентностей відкритої науки. На думку дослідників, дані компетентності мають бути інтегровані в програми аспірантури; та рекомендується координувати і поєднувати їх 3 окремими темами чи курсами академічної доброчесності. Також, на думку дослідників відкриту науку слід інтегрувати в навчальні програми окремих дисциплін.

Науковці L. Federer та J. Qin в своєму дослідженні (Federer, \& Qin, 2019) розглядають компетентності відкритої науки бібліотекарів. Оскільки, на думку науковців саме для бібліотекарів існує менше можливостей для розвитку компетентностей відкритої науки, необхідних для підтримки науки про дані. Це потрібно, щоб краще зрозуміти, як розвивати підготовку бібліотечних працівників до здійснення послуг у нових сфрерах науки про дані та відкритої науки.

Мета статті - визначити та охарактеризувати складники компетентностей відкритої науки вчителів природничо-математичних 
предметів, необхідні для роботи в науковому ліцеї, та їх взаємозв'язки.

Виклад основного матеріалу. Слід враховувати, що компетентності відкритої науки передусім потрібні вчителям природничоматематичних предметів наукових ліцеїв для того, щоб їх вихованці набували таким самих навичок, що зумовлює необхідність і доцільність демонстрації учням позитивних наслідків обміну даними та оволодіння відповідною інформацією.

Відповідно до Європейського моніторингу складники компетентностей відкритої науки (Open science monitor, 2020) можна згрупувати у чотири основні категорії, а саме:

- навички та досвід, необхідні для публікації у відкритому доступі;

- навички та досвід щодо даних досліджень, виробництва даних, управління, аналізу / використання / повторного використання, розповсюдження та зміни парадигми з «захищені дані за замовчуванням» на «відкриті дані за замовчуванням», дотримуючись законодавчих та інших обмежень;

- навички й досвід роботи у власній науковій та фаховій спільноті та поза нею;

- навички й досвід, що випливають із загальної та широкої концепції науки, коли дослідники взаємодіють із широкою громадськістю, щоб посилити вплив науки та досліджень.

Зазначені вище навички потрібні не лише науковцям, але й вчителю природничо-математичних дисциплін наукового ліцею.

Категорії компетентностей відкритої науки (Providing researchers with the skills and competencies they need to practise Open Science, 2017).

1. Компетентності щодо публікації у відкритому доступі. Бібліотечні та дослідницькі інформаційні навички (технічна / бібліотечна підтримка досліджень). Вони стосуються інтенсивного розвитку навичок фахівців академічних та науково-дослідницьких бібліотек та інформаційного професійного персоналу, що охоплює наукову підтримку, розробку та управління інформаційними системами досліджень та (в ідеалі інтегровані) інституційні сховища для окремих дисциплін, а також специфічні методи ІКТ-підтримування досліджень, нові стратегії відкритої публікації з точки зору відносин з видавцями, нові моделі фінансування та відповідні зміни в режимах публікацій. Вони охоплюють ліцензування та поради щодо авторських прав, бібліометрію та звітність про практичний вплив досліджень. Деякі з цих функцій можуть виконувати науково-дослідні працівники.

Навички грамотності щодо відкритих публікацій (на рівні користувача). Це навички, якими мають володіти дослідники, щоб зробити правильний вибір, де і як опублікувати свої результати, як і що робити для 
архівації та як передавати свої дослідження для наукового та суспільного використання.

2. Компетентності управлінням даними та відкритими даними. Технічні навички. Навички роботи з інформацією пов'язані зі збиранням відповідних наукових даних, їх анотацією та документацією, створенням метаданих, використанням таксономій та онтологій, картографуванням даних, як обробляти великі масиви даних, як правильно виконувати пошук даних, знання про існуючі сховища та як їх використовувати. Однак, слід розрізняти дослідників та технічних працівників, які $€$ «ядром» інженерії даних, які зазвичай мають підготовку в галузі IT, математики, статистики чи інженерії, та дослідників з інших галузей, які вважають такі технічні навички, як управління даними, доповнення до основної галузі досліджень. Для останнього достатньо грамотності наукових даних на рівні користувача, тоді як перша категорія - це технічні інновації для управління даними та відкритими даними (включаючи розробку стандартів та сумісності) та підтримка дослідників у розробці та технічній конфігурації дослідницьких платформ або баз даних. Технічні навички є певною мірою загальними, але в основному вони стосуються дисципліни. Тим не менше, взаємодія між дисциплінами що стосуються баз даних та методологією управління даними може створювати потенціал для виникнення нових міждисциплінарних досліджень та методологій дослідження. Проєкт EDISON містить опис кваліфікації, навичок, компетенцій та навчання, необхідних для фахівців з обробки даних (EDISON: building the data science profession, 2015). 3 наведених вище навичок у галузі інформаційних технологій, інженерія даних, аналітика даних та навички використання Big Data $€$ в центрі уваги багатьох нових навчальних програм закладів вищої освіти (ЗВО).

3. Компетентності проведення професійних досліджень. Навички управління дослідженнями. Зокрема, керівництво, управління потрібні для створення позитивного та відкритого робочого середовища. Потрібно розробити рамки організації професійної співпраці між науковими колами та промисловістю чи іншими секторами, щоб забезпечити відкритість науки (Providing researchers with the skills and competencies they need to practise Open Science, 2017). Знання про інтелектуальну власність і підприємництво $є$ особливо важливими для потенційних інноваторів. Дослідники мають бути підприємливими, знати, як отримати фінансування, як збалансувати потенційні конфлікти між розробками відкритої науки та законними інтересами щодо інтелектуальної власності, що вимагає комунікативних та лідерських навичок, окрім лише юридичних навичок.

Юридичні навички. Дослідники часто не знають про весь спектр правових аспектів, пов'язаних з інтелектуальною власністю та авторським правом, а також про використання даних та інформації. Вимоги щодо 
захисту даних можуть суперечити відкритій науці, і можуть бути певні юридичні аспекти, що стосуються конкретних дисциплін. Існуюча політика щодо дослідницьких даних часто суперечлива, залежно від того, чи переважає потенційний інтерес щодо захисту прав інтелектуальної власності.

Дослідження цілісності досліджень і навички етики. Відкрита наука робить виклик цілісності досліджень, про який дослідники не обов'язково знають. Дослідники на всіх етапах кар'єри мають бути поінформовані про важливість правильного цитування та належного розподілу досліджень, обробки конфіденційних даних (наприклад, інформації про пацієнта), у сукупності до всіх аспектів, що відповідають професійній поведінці в дослідженнях. Важливо вирішувати ці питання розсудливо, забезпечуючи довіру. Більшість випадків порушення доброчесності досліджень - це випадки недостатності уваги, а не вигадування, фальсифікації чи шахрайства. Потрібно чітко розмежувати відповідні заходи між ними. Для цього потрібні етичні навички та культурні, а також регулятивні аспекти опрацювання даних, окрім лише технічних аспектів. Крім того, хоча пропонуються курси з усіх аспектів цілісності досліджень, слід також зосередити увагу на відкритій науці через сценарії, тематичні дослідження та активне та незалежне навчання (Providing researchers with the skills and competencies they need to practise Open Science, 2017).

4. Компетентності суспільної науки - відносно нове поняття. Щоб забезпечити наукову практику для представників громадськості, вони стосуються дослідників, які вчаться взаємодіяти з громадянами, зокрема, як спілкуватись із зацікавленими сторонами, крім дослідників чи академічної наукової спільноти, з огляду на ширшу участь громадян та розповсюдження результатів досліджень. Ці навички охоплюють: здатність адекватно залучати громадян до процесів проєктування та розробки досліджень, коли це доречно, здатність залучати громадян до збирання та аналізу даних досліджень, наприклад, через наукові платформи про громадянина (Socientize тощо), i, нарешті, здатність спілкуватися, а також пояснювати та обговорювати результати досліджень із широкою громадськістю, щоб розвивати інтерес до науки та досліджень, будувати відносини довіри з суспільством та дозволяти громадянам отримувати знання та навички, які дозволять їм дискутувати з науковцями та політиками щодо наукових питань та потенційних пріоритетів більш усвідомлено. Прикладами можуть бути відвідування дослідних установ у школах, наукові тижні, фестивалі («Європейська ніч дослідників»), публічні дебати, що проводяться з науковцями та директорами з питань суспільства (Providing researchers with the skills and competencies they need to practise Open Science, 2017).

Акцентуємо увагу на питаннях практики набуття компетентностей 
відкритої науки. Так, на додаток до роботи агентств на міжнародному рівні (Providing researchers with the skills and competencies they need to practise Open Science, 2017), набуття навичок з відкритої науки передбачає підходи, методологію, політику та знання у поєднанні з іншими програмами набування навичок, що нині діють на інституційному рівні, наприклад, багато університетів проводять навчання 3 дослідницької етики та доброчесності досліджень, у науковому спілкуванні та дослідженні, інформаційній грамотності, управлінні даними, а також власне у відкритому доступі.

Незважаючи на всю вищезазначену діяльність, підготовка до використання принципів відкритої науки сприймається як недостатня для дослідників на всіх рівнях організації наукових і освітніх систем. Слід зазначити, що це не лише те, що пропонується з точки зору навчання компетентностей відкритої науки: як це сприймається науковою спільнотою і громадськістю, є принаймні настільки ж важливим. Можливості для розвитку навичок мають реалізовуватись на практиці, а не лише на навчальних курсах. Отже, засоби навчання та програми викладання та навчання, що відповідають певним навичкам та рівню організації досліджень, мають бути чітко визначені та використані. Це також стосується навчання компетентностей відкритої науки для громадян, фрахівців, представників засобів масової інформації та політиків.

Висновки і перспективи подальших досліджень. В умовах техніко-технологічних зрушень в освіті та науці для вчителя природничоматематичних дисциплін важливого значення набувають компетентності відкритої науки, що сприяють здійсненню наукової діяльності на основі співпраці, обмінів та відкритості. Для прийняття й упровадження концепції відкритої науки в освітню і наукову практику потрібна зміна культури досліджень на інституційному рівні та низка дій для досягнення цієї зміни. Компетентності відкритої науки $€$ значущими, зокрема, у контексті підготовки вчителів до роботи у наукових ліцеях. Йдеться про здатність вчителя працювати в умовах конкуренції та співпраці; використання хмарних сервісів відкритої науки; використання та повторне використання відкритих даних тощо. У контексті зазначеного вище особливо важливо значення набувають курси підвищення кваліфікації 3 розвитку компетентностей відкритої науки вчителів; МООС (теми грамотності щодо опрацювання даних та науки про дані (деякі також охоплюють основні принципи та інструменти досліджень), семінари-практикуми та онлайнкурси 3 управління даними досліджень, навчання програмному забезпеченню та опрацюванню даних.

На нашу думку, перспективними напрямами подальших досліджень вважаємо зарубіжний досвід розвитку компетентностей відкритої науки вчителів. 


\section{Список використаних джерел}

EDISON: building the data science profession. Retrieved October 21, 2020. URL: https://edison-project.eu/

Federer, L., \& Qin, J. (2019). Beyond the data management plan: Expanding roles for librarians in data science and open science. Proceedings of the Association for Information Science and Technology, 56.

Ignat, T. \& Ayris, P. (2020). Built to last! Embedding open science principles and practice into European universities. Insights, 33 (1), 9. DOI: http://doi.org/10.1629/uksg.501

Open science monitor. (n. d.). Retrieved October 19, 2020. URL: https://ec.europa.eu/info/research-and-innovation/strategy/goalsresearch-and-innovation-policy/open-science/open-sciencemonitor_en

Providing researchers with the skills and competencies they need to practise Open Science. (2017). European Union. DOI: 10.2777/121253

Schmidt, B., Orth, A., Franck, G., Kuchma, I., Knoth, P. \& Carvalho, J. (2016). Stepping up Open Science Training for European Research. Publ., 4, 16.

\section{References (translated and transliterated)}

EDISON: building the data science profession. Retrieved October 21, 2020. URL: https://edison-project.eu/ [in English].

Federer, L., \& Qin, J. (2019). Beyond the data management plan: Expanding roles for librarians in data science and open science. Proceedings of the Association for Information Science and Technology, 56. [in English].

Ignat, T. \& Ayris, P. (2020). Built to last! Embedding open science principles and practice into European universities. Insights, 33(1), 9. DOI http://doi.org/10.1629/uksg.501 [in English].

Open science monitor. (n.d.). Retrieved October 19, 2020. URL: https://ec.europa.eu/info/research-and-innovation/strategy/goalsresearch-and-innovation-policy/open-science/open-science-monitor_en [in English].

Providing researchers with the skills and competencies they need to practise Open Science. (2017). European Union. DOI:10.2777/121253 [in English].

Schmidt, B., Orth, A., Franck, G., Kuchma, I., Knoth, P. \& Carvalho, J. (2016). Stepping up Open Science Training for European Research. Publ., 4, 16 [in English]. 